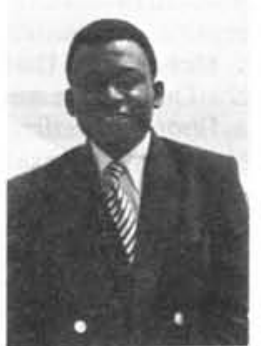

The first impression of Cornelius Adedapo Kogbe, IUGS VicePresident, is that he is a man of action, interested and involved in all aspects of African geoscience, whether engaged in training new geologists, research or administration.

Prof. Kogbe belongs to the pioneer generation of Nigerian geoscientists. He was born and raised in Jos, high on the central plateau of Nigeria in the centre of the country's tin mining region and surrounded by ring complexes, volcanoes, and Precambrian gneisses. His father was a part-time miner and the family grew up with a deep interest in geology and mining. Today two of his brothers are involved in geology and mining, and his sister is a very prominent geophysicist.

Cornelius Kogbe graduated in the early 1960s with a B.Sc. from the then new Department of Geology at the University of lbadan. He was among the first 10 geology graduates in Nigeria, a country which now trains $150-200$ geologists to the Bachelor's level each year and which has more than 2000 national geoscientists. At the time of his graduation from Ibadan, Nigeria was just beginning to develop an interest in petroleum, and in 1964 after a brief period of working in tin mining he joined Elf Aquitaine and was sent to France for fur ther training.

In France he obtained his Dr. Sc. Nat. from the Université de Lyon in 1968 and a Diplome d'Ingenieur from the Institut Français du Petrôle in 1969. He returned to Nigeria in 1969 to become Lecturer, then Senior Lecturer at the University of Ife. Seven years later he moved to Ahmadu Bello University as Professor and Head of the Department of Geology, later becoming the Dean of Science. In 1981 he moved to the University of Jos as Professor and Head of the Department of Geology and Mining. During the 1970s he was at various times Visiting Lecturer at the Technische Universität in Berlin, the Universität Heidelberg and the Université Nationale du Benin.

A few months before his graduation from the University of Ibadan, Cornelius Kogbe, a keen Christian, sat next to Bukie Oworu in a college bus conveying students to a local church outside the campus. That bus ride was remarkable for they were married six years later and now have three children (Gbenga, 12, Tope, 11, and Funml, 9). Mrs. Kogbe, a consultant ophthalmologist, finds it difficult to adjust to her husband's regular absence from home. She admits, however, that Cornelius is happiest only when life is "on the move."

There can be few African geoscientists who move with such ease between Europe and Africa and between the anglophone and francophone worlds. Despite his cosmopolitan outlook and interests, Prof. Kogbe believes that the best place to train African students is in their own country where they can work on their own problems. As he points out, if students are sent abroad they become used to "new gadgets" which are not available in their own country. Most are also trained on different terrains from those of their own countries. Thus, they are unlikely to be content at home.

Cornelius Kogbe believes that Nigeria could benefit by learning how to use its own resources better. He sees a need to concentrate on applied research, especially in the areas of engineering geology, soils, and minerals. A good example of such a project, and one in which he has taken a leading role, is the geological and geotechnical site investigations for the new Nigerian national capital, a project which involves some 50 geologists and geographers, mostly Nigerian. The work on the actual site for the city has been completed, and the focus is now on the surrounding countryside.

Prof. Kogbe also emphasizes the need for more research on Nigeria's known mineral occurrences such as uranium, lead, zinc, in the Benue Trough, and phosphates in the south of the country. There are also Cretaceous tar sands along the coast and, of course, oil both onshore and offshore. He feels that there is no need for Nigeria to remain underdeveloped, for the country has enough resources to transform itself from developing to developed status in "two decades".

But basic research is also necessary, and he says that this should focus on basement stratigraphy, granites, and orogenic episodes, with correlations required with other parts of West Africa. Much of his own research - he is the author of some 52 publications - has concentrated on regional aspects of sedimentology, palaeontology and petroleum geology. His latest monograph, "The Biostratigraphy and Sedimentology of the Nigerian Sector of the Iullemmeden Basin of West Africa", illustrates the fact that geological boundaries are not synonymous with political boundaries. Clues to a better understanding of structural and stratigraphic problems in one country may often be outside the national boundary. The IGCP Project 127 on the "Revision of the Continental Terminal Concept in Africa," of which Prof. Kogbe was group leader, provided an excellent illustration of the great advantage of the regional approach to solving geologic problems.

One of the problems in Africa in general, says Prof. Kogbe, is that there is very little real science but a great deal of bureaucracy. It is essential to "develop the human and scientific resources already in place in Africa." Many young people well trained at home or abroad are sitting in offices instead of working in the field. Laboratories are also neglected and preference is given to sending samples overseas for analysis.

Useful contributions are being made by the various activities of the Geological Society of Africa (of which he is currently the Secretary-General), IGCP, AGID, and Unesco's Geology for Development Program, but he feels that unless there is more effective participation by Africans their efforts will collapse. In order to overcome these obstacles, he believes that it would be worthwhile to set up a number of centers of excellence in science in Africa; perhaps five existing institutions in North, West, Eastern and Southern Africa could be supported strongly by international organizations and agencies.

Prof. Kogbe's tremendous energy and drive can also be seen in the new Journal of African Earth Sciences to be launched soon by Pergamon Press - he is the Editor-in-chief. At the beginning of September 1982, Prof. Kogbe became the first Director of CIFEG, the new Paris-based Centre Internationale de Formation et les Échanges Géologues, the formation of which was announced at the 1980 International Geological Congress (see EPISODES, v. 1982, No. 2, p. 39).

"Make African geoscientists feel that they are part of their problem," he stresses. "Involve them" in scientific activities, and if a model for involvement is sought Cornelius Kogbe provides an excellent one. 


\title{
CANADIAN SOCIETY OF PETROLEUM GEOLOGISTS
}

\author{
CALGARY, ALBERTA \\ LEXICON \\ OF \\ CANADIAN STRATIGRAPHY
}

I Arctic Archipelago 1981

Eds. R.L. Christie and A. Embry

Hard Cover \$8.60 Canada $\$ 10.00$ International

Soft Cover $\$ 6.60$ Canada $\$ 10.00$ International

II Yukon, Mackenzie 1981

Eds, L.V. Hills, E.V. Sangster, L.B. Suneby

Hard Cover $\$ 23.00$ Canada $\$ 24.20$ International

Soft Cover $\$ 21.00$ Canada $\$ 22.20$ International

III Western Cordillera (1982)*

Ed. W.R. Danner

IV Western Canada (1983) *

Ed. P.A. Monahan

$\checkmark$ Central Canada and St. Lawrence Lowlands (1983-84)*

Ed. Tom Bolton

VI Maritime Provinces and East Coast

Offshore (1983-84)*

Ed. Graham Williams

The Society is publishing seven Lexicons of Canadian Stratigraphy and one of Tectonic Features of Canada. Two have been published and are being distributed. It is planned to have all the volumes completed by the end of 1984 .

This is one of the major projects of the Society. It ranks with any of the previous C.S.P.G. undertakings. The co-ordinator is Dr. L.V. Hills, Department of Geology, University of Calgary. Hundreds of geologists are involved - 92 on the Committee for Volume IV on Western Canada alone.

All will be available in hard or soft cover, $16 \times 23$ $\mathrm{cm}$. Thorough bibliographies support the volumes - for example 700 references in Volume II for Yukon-MacKenzie.

VII Precambrian Shield (1984)*

VIII Tectonic Features of Canada (1984)*

Eds. Donald Cook and L.V. Hills

*Prices available after the volumes are printed.

Quoted prices include handling and mailing charges.

Send money in Canadian funds with order to -

Canadian Society of Petroleum Geologists, \#505, 206 - 7th Avenue S.W.

Calgary, Alberta T2P 0W7

Canada

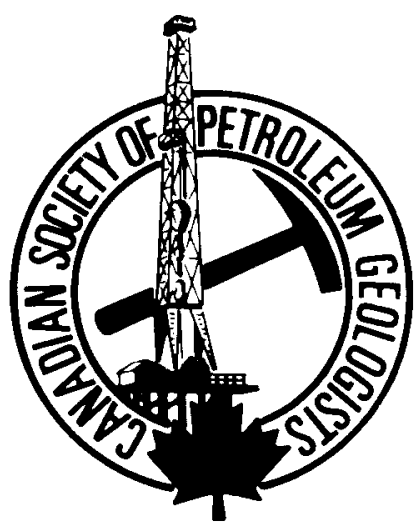

